\title{
Simultaneous Disinfection and Organic Microcontaminant Removal by UVC-LED-Driven Advanced Oxidation Processes
}

\author{
Sara Miralles-Cuevas ${ }^{1} @$, Irene De la Obra ${ }^{2,3}$, Elizabeth Gualda-Alonso ${ }^{2,3}$, Paula Soriano-Molina ${ }^{2,3}$, \\ José L. Casas López ${ }^{2,3}$ and José A. Sánchez Pérez ${ }^{2,3, *(D)}$ \\ 1 Programa Institucional de Fomento a la I+D+i, Universidad Tecnológica Metropolitana, \\ Ignacio Valdivieso 2409, San Joaquín, 8940577 Santiago, Chile; smiralles@utem.cl \\ 2 Centre (CIESOL), Joint Centre University of Almería-CIEMAT, Ctra. Sacramento s/n, 04120 Almería, Spain; \\ irene.delaobra@ual.es (I.D.1.O.); elizabeth.gualda@ual.es (E.G.-A.); psm727@ual.es (P.S.-M.); \\ jlcasas@ual.es (J.L.C.L.) \\ 3 Chemical Engineering Department, University of Almería, Ctra. Sacramento s/n, 04120 Almería, Spain \\ * Correspondence: jsanchez@ual.es
}

check for updates

Citation: Miralles-Cuevas, S.; De la Obra, I.; Gualda-Alonso, E.; Soriano-Molina, P.; Casas López, J.L.; Sánchez Pérez, J.A. Simultaneous Disinfection and Organic Microcontaminant Removal by UVC-LED-Driven Advanced Oxidation Processes. Water 2021, 13, 1507. https://doi.org/ 10.3390/w13111507

Academic Editors: Antonio Zuorro, Christos S. Akratos and Giusy Lofrano

Received: 25 April 2021

Accepted: 25 May 2021

Published: 27 May 2021

Publisher's Note: MDPI stays neutral with regard to jurisdictional claims in published maps and institutional affiliations.

Copyright: (c) 2021 by the authors. Licensee MDPI, Basel, Switzerland. This article is an open access article distributed under the terms and conditions of the Creative Commons Attribution (CC BY) license (https:// creativecommons.org/licenses/by/ $4.0 /)$.

\begin{abstract}
This work presents the comparison of four advanced oxidation processes driven by UVC-LED radiation $\left(278 \mathrm{~nm}-2 \mathrm{~W} / \mathrm{m}^{2}\right)$ for simultaneous bacteria inactivation (Escherichia coli$10^{6} \mathrm{CFU} / \mathrm{mL}$ ) and microcontaminant removal (imidacloprid-50 $\mu \mathrm{g} / \mathrm{L}$ ) in simulated wastewater secondary effluent. To this end, the activation of $\mathrm{H}_{2} \mathrm{O}_{2}$ and $\mathrm{S}_{2} \mathrm{O}_{8}{ }^{2-}$ as precursors of $\mathrm{HO}^{\bullet}$ and $\mathrm{SO}_{4}{ }^{\bullet-}$, respectively, by UVC-LED and UVC-LED/ $\mathrm{Fe}^{3+}-\mathrm{NTA}$ (ferric nitrilotriacetate at $0.1 \mathrm{mM}$ ) has been studied at different oxidant concentrations. For the purpose of comparison, conventional chlorination was used as the baseline along with bacterial regrowth $24 \mathrm{~h}$ after treatment. Disinfection was achieved within the first $30 \mathrm{~min}$ in all of the processes, mainly due to the bactericidal effect of UVC-LED radiation. UVC-LED $/ \mathrm{H}_{2} \mathrm{O}_{2}$ did not substantially affect imidacloprid removal due to the low $\mathrm{HO}^{\bullet}$ generation by UVC irradiation at $278 \mathrm{~nm}$, while more than $80 \%$ imidacloprid removal was achieved by the UVC-LED $/ \mathrm{S}_{2} \mathrm{O}_{8}{ }^{2-}$, UVC-LED $/ \mathrm{Fe}^{3+}-\mathrm{NTA} / \mathrm{S}_{2} \mathrm{O}_{8}{ }^{2-}$, and UVC-LED/ $\mathrm{Fe}^{3+}-\mathrm{NTA} / \mathrm{H}_{2} \mathrm{O}_{2}$ processes. The most efficient concentration of both oxidants for the simultaneous disinfection and microcontaminant removal was $1.47 \mathrm{mM}$. Chlorination was the most effective treatment for bacterial inactivation without imidacloprid removal. These findings are relevant for scaling up UVC-LED photoreactors for tertiary wastewater treatment aimed at removing bacteria and microcontaminants.
\end{abstract}

Keywords: light-emitting diodes; wastewater treatment; advanced oxidation processes

\section{Introduction}

In developing countries, municipal and industrial wastewater is discharged without treatment, while in developed countries $50-95 \%$ of wastewater is treated through conventional wastewater treatment plants (WWTPs) designed mainly to remove nutrients such as nitrogen, phosphorous, and carbon [1]. In recent years, the tertiary treatment of wastewater for its subsequent reuse for irrigating crops has become an essential element of the urban water cycle, and one of the best strategies for fighting water scarcity and climate change. To this end, the inactivation of pathogenic microorganisms is required, although the simultaneous removal of contaminants of emerging concern is gaining greater attention because the accumulation of these compounds implies a potential collateral effect on human populations and the environment [2]. In this regard, new quality requirements for wastewater reuse have recently been established in Europe (August 2020 in Decision 2020/1161/EU) [3].

Consequently, many researchers have emphasized the need to develop new tertiary treatments-alternatives to classical treatments such as chlorination or ozonation-since it is necessary to prevent the formation of harmful byproducts during treatments. In this sense, the advanced oxidation processes (AOPs) have been studied alongside the most 
efficient tertiary treatment options in order to remove microcontaminants and pathogens present in WWTPs' secondary effluent [4]. AOPs are based on the generation of hydroxyl radicals $\left(\mathrm{HO}^{\bullet}\right)$ (a highly oxidative species), which are very effective for microcontaminant removal as well as bacterial inactivation due to their tendency to attack pollutants unselectively [5].

In this regard, the photo-Fenton process has proven to be a very effective tertiary treatment in terms of both microcontaminant removal and bacterial inactivation. Its effectiveness depends on the large amount of $\mathrm{HO}^{\bullet}$ generated by the catalytic cycle of iron ions $\left(\mathrm{Fe}^{2+}\right.$ and $\left.\mathrm{Fe}^{3+}\right)$ combined with hydrogen peroxide and $\mathrm{UV}-\mathrm{Vis}$ radiation [6].

Recently, AOPs have been extended to include other oxidative species alternatives to hydrogen peroxide $\left(\mathrm{H}_{2} \mathrm{O}_{2}\right)$, such as peroxydisulfate $\left(\mathrm{S}_{2} \mathrm{O}_{8}{ }^{2-}\right)$. These AOPs are based on the generation of sulfate radical anions $\left(\mathrm{SO}_{4}{ }^{\bullet-}\right)$ instead of $\mathrm{HO}^{\bullet}$. This radical has attracted much attention due to its higher redox potential (2.5-3.1 V, dependent on $\mathrm{pH}$ ) compared to $\mathrm{HO}^{\bullet}$ $(\sim 2.8 \mathrm{~V})$ [7]. Additionally, it has a longer lifetime (around 30-40 $\mu$ s) and a higher selectivity towards electron-rich organic pollutants, which offer great advantages [8]. Furthermore, recent studies have also demonstrated successful results using $\mathrm{SO}_{4}{ }^{\bullet-}$ for microcontaminant degradation as well as pathogen inactivation [9].

Another aspect that must be considered is the process' $\mathrm{pH}$. Although an acidic $\mathrm{pH}$ is considered to be optimal for carrying out the photo-Fenton process, since $\mathrm{Fe}^{3+}$ may be held in solution, a growing number of studies have demonstrated the efficiency of the process at neutral $\mathrm{pH}$ for bacterial inactivation as well as microcontaminant removal. For that purpose, the use of iron chelating agents has emerged as a good solution to keep iron in solution during the reaction. Recently, nitrilotriacetic acid (NTA) has been reported as a cheaper alternative than other, more expensive chelating agents with similar effectiveness [10].

On the other hand, photo-driven processes where natural light can be replaced by low-energy artificial light are emerging [11]. In this regard, the use of light-emitting diodes (LEDs) as a replacement for mercury lamps as a source of UV radiation is gaining growing interest [12]. This system has significant advantages, such as low power consumption, long lifetime $(100,000 \mathrm{~h})$, high spectral purity, uniform illumination, energy efficiency, and flexible configuration [13]. In terms of the emitting wavelength, the UV radiation electromagnetic spectrum is divided into UVA (315-400 nm), UVB (280-315 nm), and UVC (100-280 nm), with photonic energy of 3.10-3.94 eV, 3.94-4.43 eV, and 4.43-12.40 eV, respectively. UVA is the most used radiation in terms of microcontaminant removal, showing successful results [14]. In this regard, the bacterial inactivation efficiency of LEDs depends on the wavelength and the spectral distribution of the light source. Today, UVC treatment is widely applied, mainly in drinking water disinfection devices and small household systems, since UVC irradiation effectively eliminates fungi, yeasts, viruses, and bacteria, without chemical residues, corrosion, or harmful additives [15]. UVC-LED technology is booming, and today, 254-nm LEDs are available, although their cost is not yet competitive.

For the first time, this work addresses the comparison of four AOPs based on $\mathrm{HO}^{\bullet}$ and $\mathrm{SO}_{4}{ }^{\bullet-}$ generation under UVC-LED radiation at $278 \mathrm{~nm}$, in order to evaluate their performance in simultaneous Escherichia coli (E. coli K-12) inactivation and imidacloprid (IMD) removal in simulated WWTP secondary effluent. The UVC-LED $/ \mathrm{H}_{2} \mathrm{O}_{2}, \mathrm{UVC}$ $\mathrm{LED} / \mathrm{S}_{2} \mathrm{O}_{8}{ }^{2-}$, UVC-LED $/ \mathrm{Fe}^{3+}-\mathrm{NTA} / \mathrm{H}_{2} \mathrm{O}_{2}$, and UVC-LED $/ \mathrm{Fe}^{3+}-\mathrm{NTA} / \mathrm{S}_{2} \mathrm{O}_{8}{ }^{2-}$ processes were evaluated and compared with chlorination, currently the most widely used conventional tertiary treatment. This study is the first evaluation of the use of iron complexes at low wavelengths with UVC-LED radiation.

\section{Materials and Methods}

\subsection{Reagents and Water Matrix}

Imidacloprid (IMD, >99\%) was selected as model pesticide. This microcontaminant was supplied by Sigma-Aldrich, as along with nitrilotriacetic acid (NTA), $(>99 \%, w / w)$ 
which was used as complexing agent. Ferric sulfate monohydrate $\left(\mathrm{Fe}_{2}\left(\mathrm{SO}_{4}\right)_{3} \cdot \mathrm{H}_{2} \mathrm{O}(75 \%\right.$, $w / w))$, hydrogen peroxide $\left(\mathrm{H}_{2} \mathrm{O}_{2}, 33 \% w / v\right)$, methanol, glacial acetic acid $(>99 \%, w / v)$, ortho-phenanthroline $(99 \%, w / w)$, and sulfuric acid $(96 \%, w / v)$ were supplied by Panreac. A Milli- ${ }^{\circledR}$ water purification system with a specific resistance of $18.2 \mathrm{M} \Omega \mathrm{cm}$ and $5 \mu \mathrm{g} / \mathrm{L}$ of dissolved organic carbon (DOC) was used to prepare the solutions during the experiments. Sodium bicarbonate $\left(\mathrm{NaHCO}_{3}\right)$ and potassium iodide $(\mathrm{KI})$ were acquired from Ridel-deHaën and Sigma-Aldrich, respectively. Sodium peroxydisulfate $\left(\mathrm{Na}_{2} \mathrm{~S}_{2} \mathrm{O}_{8}\right)$ and Chromocult medium were provided by Merck. Lastly, sodium hypochlorite $(\mathrm{NaClO})$ ( $40 \mathrm{~g} / \mathrm{L}$ of active chlorine) was supplied by Sigma-Aldrich. Catalase from bovine liver and sodium thiosulfate $(10 \%)\left(\mathrm{Na}_{2} \mathrm{~S}_{2} \mathrm{O}_{3}\right)$, provided by Sigma-Aldrich and Merck (Spain), respectively, were both used as quenchers of $\mathrm{H}_{2} \mathrm{O}_{2}$ and $\mathrm{S}_{2} \mathrm{O}_{8}{ }^{2-}$ /chlorine.

The experiments were carried out in simulated WWTP secondary effluent. This matrix is more stable, and allows us to avoid the variability and potential fluctuations related to real effluent. The matrix composition was previously reported by Rivas et al. (2015) [16]; Its main physical and chemical parameters are: $\mathrm{pH}(7.3 \pm 0.3)$; turbidity $(2.2 \pm 0.3 \mathrm{NTU})$; chemical oxygen demand $(42.0 \pm 2.0 \mathrm{mg} / \mathrm{L})$; sulfates $(98.8 \pm 13.0)$; and chlorides $(2.0 \pm 0.3 \mathrm{mg} / \mathrm{L})$. In terms of DOC and total inorganic carbon (TIC) concentrations, samples were measured and monitored during the trials, showing initial values of around $10 \mathrm{mg} / \mathrm{L}$ and $15 \mathrm{mg} / \mathrm{L}$, respectively.

\subsection{Experimental Setup}

\subsubsection{Experimental UVC-LED System}

This work was carried out in a lab-scale photoreactor whose design is represented in Figure 1. The UVC radiation source included seven LEDs provided by Robotecno S.L (Almería, Spain). The diodes were connected in series-three in a line and four drawing a square around the others, as shown in Figure 1-working at $100 \mathrm{~mA}$ and $6.5 \mathrm{~V}$. A cylindrical glass reactor $13.5 \mathrm{~cm}$ in diameter with a magnetic stirrer was used. The reactor was filled with $650 \mathrm{~mL}$ of simulated WWTP secondary effluent, corresponding to $5 \mathrm{~cm}$ of liquid depth.

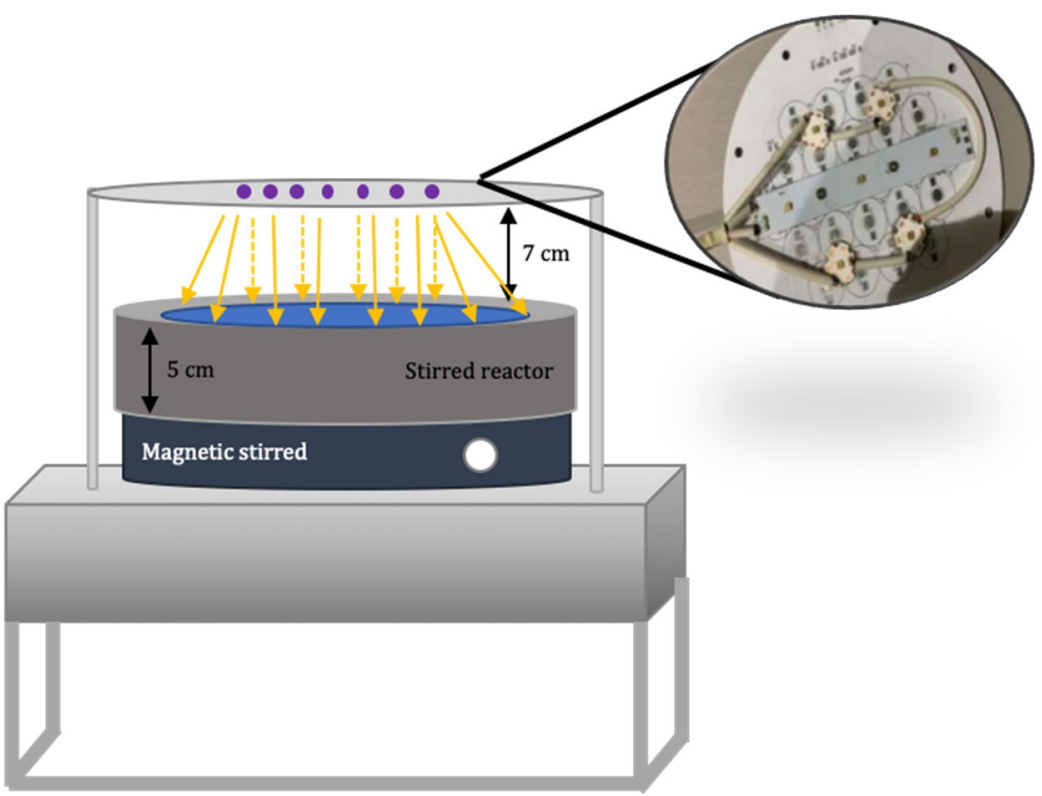

Figure 1. Design of the experimental UVC-LED device.

The UVC-LEDs' emission spectrum was measured using an Avantes AvaSpec-ULS2048-2 spectroradiometer, showing the emission peak at $278 \mathrm{~nm}$, with a full width at half maximum (FWHM) of $40 \mathrm{~nm}$. The radiation distribution of the system was measured considering the dimensions of the reactor, the average irradiance being $2.02 \pm 0.65 \mathrm{~W} / \mathrm{m}^{2}$. As can be seen in Figure 2, the reactor's entire surface was irradiated. 


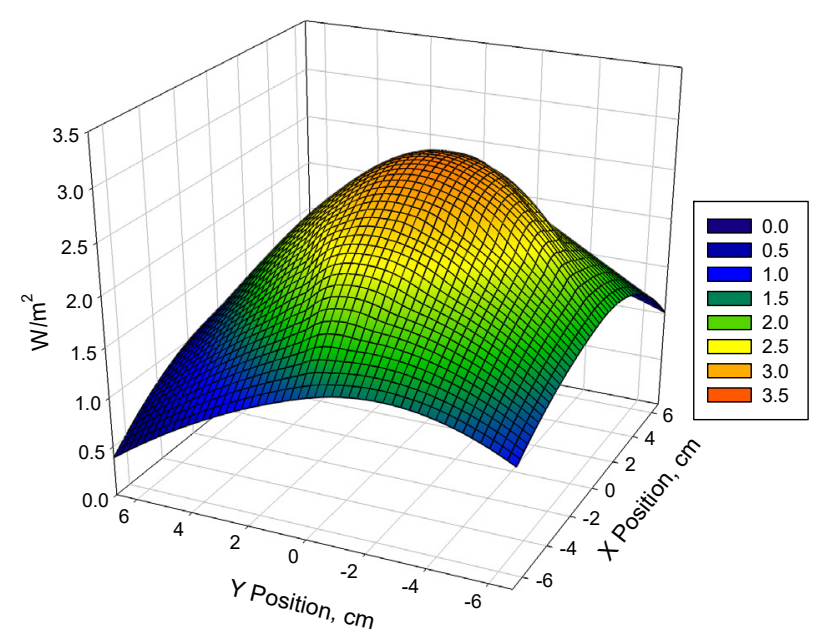

Figure 2. The UVC-LED system's radiation distribution.

The photon flow received was measured using the chemical actinometry protocol described in [17], and was $0.1 \mu$ Einstein $/ \mathrm{s}$ at $278 \mathrm{~nm}$.

The UVC dose $\left(\mathrm{kJ} / \mathrm{m}^{2}\right)$, and the accumulative UVC energy, $\mathrm{QUVC}_{\mathrm{UV}}(\mathrm{kJ} / \mathrm{L})$, were calculated using Equations (1) and (2), in order to compare the energy requirements of these processes with other photochemical-based systems:

$$
\begin{gathered}
\text { UVC Dose }=\mathrm{I} \cdot \mathrm{t} \\
\mathrm{QuVC}_{\mathrm{UVC}}=\mathrm{UVC} \text { Dose } \cdot \frac{\mathrm{S}_{\mathrm{i}}}{\mathrm{V}_{\mathrm{T}}}
\end{gathered}
$$

where I is the UVC irradiation emitted by the system $\left(\mathrm{W} / \mathrm{m}^{2}\right), \mathrm{t}$ is the illumination time (s), $S_{i}$ is the total irradiated surface of the photoreactor $\left(\mathrm{m}^{2}\right)$, and $V_{T}$ is the total water volume (L).

\subsubsection{Experimental UVC-LED System}

To carry out the experiment, batches of $10 \mathrm{~L}$ of simulated WWTP secondary effluent were prepared. This simulated effluent was not used for longer than 3 days. The initial $\mathrm{pH}$ values ranged from 7.0 to 7.5 . The $\mathrm{pH}$ did not show any significant change during the experiments. All of the trials were performed at room temperature. The matrix was doped with an initial concentration of $50 \mu \mathrm{g} / \mathrm{L}$ of IMD as a model microcontaminant, and E. coli $\mathrm{K}-12$ ATCC 23631 as model bacteria, at an initial concentration of $10^{6} \mathrm{CFU} / \mathrm{mL}$. IMD was selected since it is included in the watch-list-reported Decision 2018/840/EU of 5 June 2018 [18], and the E. coli concentration was selected so as to be able to follow the kinetics of bacteria inactivation. Several samples were collected periodically for $1 \mathrm{~h}$ of the experiment in order to monitor both E. coli inactivation and IMD removal. In the corresponding samples, $50 \mu \mathrm{L} / \mathrm{mL}$ of catalase was added in order to remove $\mathrm{H}_{2} \mathrm{O}_{2}$ residue, and $10 \mu \mathrm{L} / \mathrm{mL}$ of sodium thiosulfate solution $(10 \%)$ was added in order to remove $\mathrm{S}_{2} \mathrm{O}_{8}{ }^{2-}$ or active chlorine.

Control experiments were carried out following both the inactivation of E. coli K-12 and the degradation of the pesticide IMD under the same established conditions. These controls comprised the effects of both oxidants- $-\mathrm{H}_{2} \mathrm{O}_{2}$ and $\mathrm{S}_{2} \mathrm{O}_{8}{ }^{2-}$-as well as the effect of the $\mathrm{Fe}^{3+}-\mathrm{NTA}$ complex in the absence of light. No effect was observed in any case for $E$. coli inactivation, while only $55 \%$ IMD removal was observed due to the Fenton-like reaction $\left(\mathrm{Fe}^{3+}-\mathrm{NTA} / \mathrm{H}_{2} \mathrm{O}_{2}\right)$ (data not shown).

The combination of UVC-LED with both oxidants- $-\mathrm{H}_{2} \mathrm{O}_{2}$ and $\mathrm{S}_{2} \mathrm{O}_{8}{ }^{2-}-$ was studied at three initial concentrations- $0.147,1.47$, and $2.94 \mathrm{mM}-$ in order to achieve complete E. coli K-12 inactivation without regrowth at $24 \mathrm{~h}$. In a second step, the best concentration of both oxidants $(1.47 \mathrm{mM})$ was evaluated, adding NTA as a chelating agent $(0.1 \mathrm{mM}$ 
$\mathrm{Fe}^{3+}-\mathrm{NTA}$, molar ratio of 1:1). $\mathrm{Fe}^{3+}-\mathrm{NTA}$ concentration and molar ratio were selected based on a previous work conducted under solar radiation [19]. Finally, chlorination at $0.03,0.14$, and $0.28 \mathrm{mM}(1,5$, and $10 \mathrm{mg} / \mathrm{L}$ of chlorine) was studied for comparative purposes. The chlorine concentration range was selected seeking the best compromise between residual chlorine concentration as recommended by the Guidelines for Water Reuse, EPA [20] (below $0.5 \mathrm{mg} / \mathrm{L}$ of residual chlorine), and complete E. coli inactivation without regrowth at $24 \mathrm{~h}$. All of the experiments were carried out in duplicate, and all of the figures show mean values \pm standard deviation.

\subsubsection{Analytical Determinations}

Both iron and oxidant concentrations were measured by standardized spectrophotometric methods. The o-phenanthroline standardized method (ISO 6332) was selected to determine the total concentration of dissolved iron. The titanium(IV) oxysulfate solution spectrophotometric method at $410 \mathrm{~nm}$ (method DIN $38402 \mathrm{H} 15$ ) was chosen for the $\mathrm{H}_{2} \mathrm{O}_{2}$ concentration. $\mathrm{S}_{2} \mathrm{O}_{8}{ }^{2-}$ concentration was measured using the iodide method at $352 \mathrm{~nm}$ [21]. The limits of quantification (LOQs) were $2.9 \cdot 10^{-2} \mathrm{mM}, 3.6 \cdot 10^{-3} \mathrm{mM}$, and $5.0 \cdot 10^{-2} \mathrm{mM}$ for hydrogen peroxide, total dissolved iron, and persulfate, respectively. Finally, free chlorine and total chlorine were determined using a kit supplied by Merck S.L and measured using a spectrophotometer at $530 \mathrm{~nm}$. UV-Vis absorbances were measured using a Thermo Fisher Scientific GENESYS 50 UV-Vis spectrophotometer (Waltham, MA, USA). IMD was monitored and quantified via ultra-pressure liquid chromatography coupled with a diode array detector (UPLC/DAD-UV) (Agilent Technologies, Series 1200, Waldbronn, Germany). The chromatography column used was a C-18 analytical column model ZORBAX XDB-C18 ECLIPSE (Waldbronn, Germany) $4.6 \times 50 \mathrm{~mm} 1.8 \mu \mathrm{m}$. This quantification method was previously reported by Mejri et al. in 2020 [19]. $\mathrm{Fe}^{3+}-\mathrm{NTA}$ was determined according to the method previously described by Zhang et al. (2017), as well as by UPLC/DAD-UV [22], with a LOQ of $2 \cdot 10^{-4} \mathrm{mM}$. DOC and TIC were quantified using a Shimadzu TOC-VCSN analyzer (Shimadzu Corporation, Kyoto, Japan) with an LOQ of $1 \mathrm{mg} / \mathrm{L}$ in both cases.

\subsubsection{Bacterial Enumeration and Quantification}

Escherichia coli K-12 ATCC 23631 was inoculated using Luria broth nutrient medium (Miller's LB Broth, Sigma-Aldrich, St. Louis, MO, USA) and incubated at $37^{\circ} \mathrm{C}$ for $20 \mathrm{~h}$. The standard procedure by which to achieve $10^{6} \mathrm{CFU} / \mathrm{mL}$ as an initial concentration was previously described by García-Fernández et al. in 2012 [23]. Furthermore, several samples were collected and measured during the experiment, using a plate-counting technique with a detection limit (DL) of $1 \mathrm{CFU} / \mathrm{mL}$. In addition, in order to study bacterial regrowth in all experiments in which the bacterial concentration was lower than the DL, $100 \mathrm{~mL}$ samples were processed using the membrane filtration method in order to achieve the minimum disinfection level $\left(\mathrm{DL}_{\mathrm{EU}}=10 \mathrm{CFU} / 100 \mathrm{~mL}\right.$ ) required by the new Regulation (EU) 2020/741 of the European Parliament and of the Council of 25 May 2020 (Regulation (EU) 2020/741) [24]. For this purpose, cellulose nitrate membrane (Sartorius) filters of 0.45 $\mu \mathrm{m}$ pore size were used. These filters were plated in Chromocult medium and incubated at $37^{\circ} \mathrm{C}$ for $24 \mathrm{~h}$.

\section{Results and Discussion}

\subsection{Simultaneous E. coli Inactivation and IMD Removal by UVC-LED/ $\mathrm{H}_{2} \mathrm{O}_{2}$ and} UVC-LED $/ \mathrm{S}_{2} \mathrm{O}_{8}{ }^{2-}$ Processes

\subsubsection{Effect of $\mathrm{H}_{2} \mathrm{O}_{2}$ Concentration}

Under UVC irradiation $\mathrm{H}_{2} \mathrm{O}_{2}$ decomposes to produce two hydroxyl radicals (Reaction (R1)). In addition, the presence of this oxidant promotes the generation of hydroperoxide radicals $\left(\mathrm{HO}_{2}{ }^{\bullet}\right)$ and superoxide radical anions $\left(\mathrm{O}_{2}{ }^{\bullet-}\right)$ through Reactions (R2-R5) [25], which also contribute to the oxidation of microcontaminants and the inactivation of microorganisms. 


$$
\begin{gathered}
\mathrm{H}_{2} \mathrm{O}_{2}+\mathrm{hv} \rightarrow 2 \mathrm{HO}^{\bullet} \\
\mathrm{H}_{2} \mathrm{O}_{2}+\mathrm{HO}^{\bullet} \rightarrow \mathrm{H}_{2} \mathrm{O}+\mathrm{HO}_{2}^{\bullet} \\
2 \mathrm{HO}_{2}^{\bullet} \rightarrow \mathrm{H}_{2} \mathrm{O}_{2}+\mathrm{O}_{2} \\
\mathrm{H}_{2} \mathrm{O}_{2}+\mathrm{HO}_{2}^{\bullet} \rightarrow \mathrm{HO}^{\bullet}+\mathrm{H}_{2} \mathrm{O}+\mathrm{O}_{2} \\
\mathrm{H}_{2} \mathrm{O}_{2}+\mathrm{HO}^{\bullet} \rightarrow \mathrm{O}_{2}^{\bullet-}+\mathrm{H}^{+}+\mathrm{H}_{2} \mathrm{O}
\end{gathered}
$$

Figure 3 shows the profiles of $E$. coli inactivation and IMD removal by UVC-LED alone and by UVC-LED $/ \mathrm{H}_{2} \mathrm{O}_{2}$ processes. As can be observed, in the absence of oxidant, a fast bacterial inactivation (5-logs reduced) was achieved in the first 20 min of treatment. Then, the inactivation rate slowed down, and the DL was not reached in $60 \mathrm{~min}$ of reaction (Figure $3 \mathrm{~A}$ ). The presence of $\mathrm{H}_{2} \mathrm{O}_{2}$ at $0.147 \mathrm{mM}$ of initial concentration did not improve bacterial inactivation. However, increasing the initial concentration of oxidant to 1.47 and $2.94 \mathrm{mM}$, the pseudo-first-order constants were 1.6 and 1.7 times higher, respectively, with regard to the UVC-LED treatment (Table 1), and the inactivation below the DL was achieved in $20 \mathrm{~min}$ (UVC dose of $2.4 \mathrm{~kJ} / \mathrm{m}^{2}$ or $0.05 \mathrm{~kJ} / \mathrm{L}$ ) and $10 \mathrm{~min}$ (UVC dose of $1.2 \mathrm{~kJ} / \mathrm{m}^{2}$ or $0.03 \mathrm{~kJ} / \mathrm{L})$, respectively.
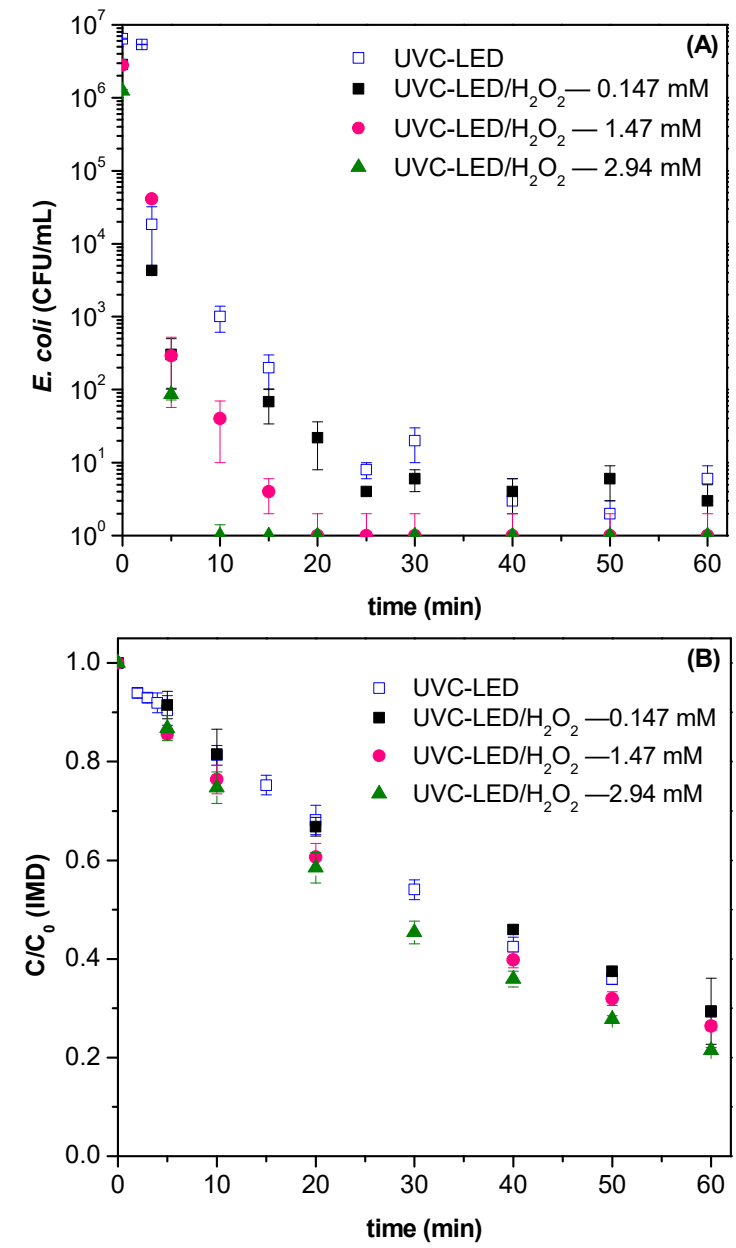

Figure 3. Effect of the initial concentration of $\mathrm{H}_{2} \mathrm{O}_{2}(0.147,1.47$, and $2.94 \mathrm{mM})$ on simultaneous E. coli inactivation (A) and IMD removal (B) by UVC-LED $/ \mathrm{H}_{2} \mathrm{O}_{2}$ process. 
Table 1. Pseudo-first-order kinetic constants of E. coli inactivation and IMD removal, dose, accumulate energy, and disinfection/decontamination time for complete E. coli inactivation and more than $80 \%$ IMD removal for all treatments discussed in this study.

\begin{tabular}{|c|c|c|c|c|c|}
\hline Treatments & $\begin{array}{l}\mathbf{k}_{E . c o l i} \pm \mathrm{SD} \\
\quad\left(\min ^{-1}\right)\end{array}$ & $\begin{array}{l}\mathrm{k}_{\mathrm{IMD}} \pm \mathrm{SD} \\
\quad\left(\min ^{-1}\right)\end{array}$ & $\begin{array}{l}\text { Time } \\
\text { E. coli/IMD } \\
\text { (min) }\end{array}$ & $\begin{array}{l}\text { UV Dose } \\
\text { E. coli/IMD } \\
\left(\mathrm{kJ} / \mathrm{m}^{2}\right)\end{array}$ & $\begin{array}{c}\mathrm{Q}_{\mathrm{UVC}} \\
\text { E. coli/IMD } \\
(\mathrm{kJ} / \mathrm{L})\end{array}$ \\
\hline UVC-LED & $\begin{array}{l}0.93 \pm 0.20 \\
\mathrm{R}^{2}=0.950\end{array}$ & $\begin{array}{c}0.021 \pm 0.002 \\
\mathrm{R}^{2}=0.976\end{array}$ & $-{ }^{*}$ & - & - \\
\hline UVC-LED $/ \mathrm{H}_{2} \mathrm{O}_{2}-0.147 \mathrm{mM}$ & $\begin{array}{l}0.94 \pm 0.25 \\
\mathrm{R}^{2}=0.948\end{array}$ & $\begin{array}{l}0.020 \pm 0.001 \\
R^{2}=0.999\end{array}$ & $>60 />60$ & $>7.2 /-$ & $>0.16 /-$ \\
\hline UVC-LED $/ \mathrm{H}_{2} \mathrm{O}_{2}-1.47 \mathrm{mM}$ & $\begin{array}{c}1.5 \pm 0.3 \\
R^{2}=0.969\end{array}$ & $\begin{array}{c}0.022 \pm 0.003 \\
R^{2}=0.999\end{array}$ & $20 />60$ & $2.4 /-$ & $0.05 /-$ \\
\hline $\mathrm{UVC}-\mathrm{LED} / \mathrm{H}_{2} \mathrm{O}_{2}-2.94 \mathrm{mM}$ & $\begin{array}{c}1.5 \pm 0.2 \\
\mathrm{R}^{2}=0.977\end{array}$ & $\begin{array}{c}0.025 \pm 0.001 \\
\mathrm{R}^{2}=0.999\end{array}$ & $10 />60$ & $1.2 /-$ & $0.03 /-$ \\
\hline UVC-LED $/ \mathrm{S}_{2} \mathrm{O}_{8}{ }^{2-}-0.147 \mathrm{mM}$ & $\begin{array}{c}1.3 \pm 0.2 \\
R^{2}=0.952\end{array}$ & $\begin{array}{c}0.019 \pm 0.001 \\
R^{2}=0.997\end{array}$ & $20 />60$ & $2.4 /-$ & $0.05 /-$ \\
\hline UVC-LED $/ \mathrm{S}_{2} \mathrm{O}_{8}{ }^{2-}-1.47 \mathrm{mM}$ & $\begin{array}{c}1.6 \pm 0.3 \\
R^{2}=0.950\end{array}$ & $\begin{array}{c}0.044 \pm 0.001 \\
R^{2}=0.907\end{array}$ & $20 / 40$ & $2.4 / 4.8$ & $0.05 / 0.11$ \\
\hline $\mathrm{UVC}-\mathrm{LED} / \mathrm{S}_{2} \mathrm{O}_{8}{ }^{2-}-2.94 \mathrm{mM}$ & $\begin{array}{c}1.7 \pm 0.2 \\
\mathrm{R}^{2}=0.950\end{array}$ & $\begin{array}{c}0.058 \pm 0.001 \\
\mathrm{R}^{2}=0.997\end{array}$ & $15 / 25$ & $1.8 / 3.0$ & $0.04 / 0.07$ \\
\hline \multirow{2}{*}{$\begin{array}{c}\text { UVC-LED } / \mathrm{Fe}^{3+}-\mathrm{NTA} / \\
\mathrm{H}_{2} \mathrm{O}_{2}-0.1 \mathrm{mM} / 1.47 \mathrm{mM} \\
\text { UVC-LED } / \mathrm{Fe}^{3+} \\
\text { NTA } / \mathrm{S}_{2} \mathrm{O}_{8}{ }^{2-} \\
-0.1 \mathrm{mM} / 1.47 \mathrm{mM}\end{array}$} & $\begin{array}{l}0.430 \pm 0.007 \\
\mathrm{R}^{2}=0.928\end{array}$ & $\begin{array}{l}0.081 \pm 0.001 \\
\mathrm{R}^{2}=0.998\end{array}$ & $30 / 20$ & $3.6 / 2.4$ & $0.08 / 0.05$ \\
\hline & $\begin{array}{c}0.450 \pm 0.006 \\
R^{2}=0.949\end{array}$ & $\begin{array}{c}0.033 \pm 0.001 \\
\mathrm{R}^{2}=0.994\end{array}$ & $30 / 55$ & $3.6 / 6.6$ & $0.08 / 0.14$ \\
\hline Chlorination $-0.028 \mathrm{mM}$ & $\begin{array}{l}0.360 \pm 0.002 \\
\mathrm{R}^{2}=0.960\end{array}$ & - & $>30$ & - & - \\
\hline Chlorination $-0.14 \mathrm{mM}$ & $\begin{array}{c}1.7 \pm 0.1 \\
\mathrm{R}^{2}=0.969\end{array}$ & - & 10 & - & - \\
\hline Chlorination $-0.28 \mathrm{mM}$ & $\begin{array}{c}3.1 \pm 0.6 \\
\mathrm{R}^{2}=0.989\end{array}$ & - & 5 & - & - \\
\hline
\end{tabular}

* - Indicates that $80 \%$ of IMD elimination or complete disinfection for 60 min of treatment were not achieved.

Bacterial regrowth was also assessed for the experiments in which the DL was reached. In addition, considering the new Regulation (EU) 2020/741 of the European Parliament and of the Council of 25 May 2020 on the minimum requirements for water reuse [24], a new detection limit (DLEU) was set at $10 \mathrm{CFU} / 100 \mathrm{~mL}$. With both $1.47 \mathrm{mM}$ and $2.94 \mathrm{mM}$ of $\mathrm{H}_{2} \mathrm{O}_{2}$, there was no regrowth above the DLEU after $24 \mathrm{~h}$, and the residual concentrations of $\mathrm{H}_{2} \mathrm{O}_{2}$ were $1.33 \mathrm{mM}$ and $2.52 \mathrm{mM}$, respectively. These results are in concordance with previous studies that point out that the presence of a residual concentration of $\mathrm{H}_{2} \mathrm{O}_{2}$ in reclaimed water prevents microbial regrowth during the water distribution process [26]. Moreover, toxicity studies have demonstrated that residual concentrations less than $1.47 \mathrm{mM}$ do not cause any risk for water reuse in agricultural irrigation [27]. Considering this, applying the UVC-LED $/ \mathrm{H}_{2} \mathrm{O}_{2}$ process at an oxidant concentration of $1.47 \mathrm{mM}$ would be recommended for bacterial inactivation, as it enhances the inactivation rate, avoiding both regrowth and an excess of $\mathrm{H}_{2} \mathrm{O}_{2}$ above the limit value.

Concerning microcontaminant removal, Figure 3B shows a slight positive effect of $\mathrm{H}_{2} \mathrm{O}_{2}$ at $2.94 \mathrm{mM}$ of initial concentration, achieving 78\% IMD degradation after $60 \mathrm{~min}$ of reaction, with $\mathrm{H}_{2} \mathrm{O}_{2}$ consumption of $0.26 \mathrm{mM}$. At lower $\mathrm{H}_{2} \mathrm{O}_{2}$ concentrations, IMD degradation rates were similar to those of the assays in the absence of oxidants (IMD photolysis), as shown in Table 1 , achieving $71 \%$ and $73 \%$ pesticide removal, and $\mathrm{H}_{2} \mathrm{O}_{2}$ consumption was $0.081 \mathrm{mM}$ and $0.22 \mathrm{mM}$ for initial concentrations of $0.147 \mathrm{mM}$ and $1.47 \mathrm{mM}$, respectively. These results show that although the use of $\mathrm{H}_{2} \mathrm{O}_{2}$ in combination with UVC-LED (278 nm) enhances bacterial inactivation, it does not substantially affect microcontaminant removal. The low contribution of $\mathrm{H}_{2} \mathrm{O}_{2}$ to IMD removal could be 
explained by the low photoactivation of $\mathrm{H}_{2} \mathrm{O}_{2}$ at $278 \mathrm{~nm}$ when compared with $254 \mathrm{~nm}$ (a radiation wavelength commonly applied in UVC processes), leading to a lower efficiency of hydroxyl radical generation. In this work, the molar decadic absorption coefficient of $\mathrm{H}_{2} \mathrm{O}_{2}$ obtained from spectral measurements is $0.60 \mathrm{mM}^{-1} \mathrm{~m}^{-1}$ at $278 \mathrm{~nm}$, whereas at $254 \mathrm{~nm}$ the value is $2.13 \mathrm{mM}^{-1} \mathrm{~m}^{-1}$. Consequently, the effect on bacterial inactivation would be mainly due to the combination of the bactericidal effect of UVC-LED radiation and the oxidizing power of $\mathrm{H}_{2} \mathrm{O}_{2}$ at high concentrations, and not to the generation of hydroxyl radicals by $\mathrm{H}_{2} \mathrm{O}_{2}$ photoactivation.

\subsubsection{Effect of $\mathrm{S}_{2} \mathrm{O}_{8}{ }^{2-}$ Concentration}

$\mathrm{S}_{2} \mathrm{O}_{8}{ }^{2-}$ is also a strong oxidant $\left(\mathrm{E}_{0}=2.01 \mathrm{~V}\right.$ at neutral $\left.\mathrm{pH}\right)$, which decomposes under $\mathrm{UVC}$ radiation, generating two sulfate radicals $\left(\mathrm{SO}_{4}{ }^{--}\right)$and promoting highly oxidizing radical reactions (Reactions (R6-R8)) [25]:

$$
\begin{gathered}
\mathrm{S}_{2} \mathrm{O}_{8}^{2-}+\mathrm{h} v \rightarrow 2 \mathrm{SO}_{4}^{\bullet-} \\
\mathrm{SO}_{4}^{\bullet-}+\mathrm{RH}_{2} \rightarrow \mathrm{SO}_{4}^{2-}+\mathrm{H}^{+}+\mathrm{RH}^{\bullet} \\
\mathrm{RH}^{\bullet}+\mathrm{S}_{2} \mathrm{O}_{8}^{2-} \rightarrow \mathrm{R}+\mathrm{SO}_{4}^{2-}+\mathrm{SO}_{4}^{\bullet-}
\end{gathered}
$$

Figure 4 shows the profiles of E. coli inactivation and IMD removal by the UVC-LED and UVC-LED $/ \mathrm{S}_{2} \mathrm{O}_{8}{ }^{2-}$ processes. The presence of oxidants in the reaction bulk accelerated the rate of E. coli inactivation, with the pseudo-first-order rate constants for the three concentrations tested being between 1.4 and 1.8 times higher with regard to the absence of oxidants, as shown in Table 1. The inactivation times ranged between $15 \mathrm{~min}$ (UVC dose of $1.8 \mathrm{~kJ} / \mathrm{m}^{2}$ or $0.04 \mathrm{~kJ} / \mathrm{L}$ ) and $20 \min$ (UVC dose of $2.4 \mathrm{~kJ} / \mathrm{m}^{2}$ or $0.05 \mathrm{~kJ} / \mathrm{L}$ ).

Concerning bacterial regrowth, although with $0.147 \mathrm{mM}$ of $\mathrm{S}_{2} \mathrm{O}_{8}{ }^{2-}$ the DL of $1 \mathrm{CFU} / \mathrm{mL}$ was reached, regrowth occurred after $24 \mathrm{~h}$ of the treatment, probably due to the low residual oxidant concentration (below the LOQ). This is in concordance with the results obtained by Sánchez-Montes et al. (2020) [28], who reported that $\mathrm{S}_{2} \mathrm{O}_{2}{ }^{8-}$ concentrations up to $0.23 \mathrm{mM}$ do not prevent bacterial regrowth, because it has no bactericidal effect by itself. However, with $1.47 \mathrm{mM}$ and $2.94 \mathrm{mM}$, there was no regrowth below the $\mathrm{DL}_{\mathrm{EU}}$ of $10 \mathrm{CFU} / 100 \mathrm{~mL}$, the residual concentrations being $0.92 \mathrm{mM}$ and $1.50 \mathrm{mM}$, respectively. This could be due to the amount of sulfate radicals generated by photoactivation of $\mathrm{S}_{2} \mathrm{O}_{2}{ }^{8-}$ at concentrations above $1.47 \mathrm{mM}$ being enough to prevent further regrowth.

As for the microcontaminant, on the one hand the profiles of IMD removal by UVCLED and $\mathrm{UVC} / \mathrm{S}_{2} \mathrm{O}_{8}{ }^{2-}(0.147 \mathrm{mM})$ overlapped, as shown in Figure $4 \mathrm{~B}$, noting that there was no effect of persulfate on IMD removal at the lowest concentration tested. On the other hand, when increasing the oxidant concentration to $1.47 \mathrm{mM}$ and $2.94 \mathrm{mM}$, the removal rates were 2.2 and 2.9 times faster, respectively, as shown in Table 1 . After $60 \mathrm{~min}$ of the reaction with $0.147 \mathrm{mM}$ of $\mathrm{S}_{2} \mathrm{O}_{8}{ }^{2-}$, the removal percentage was $67 \%$, corresponding to the percentage of pesticide removal by UVC-LED photolysis. However, with $1.47 \mathrm{mM}$ and $2.94 \mathrm{mM}$ of $\mathrm{S}_{2} \mathrm{O}_{8}{ }^{2-}$, the values were $93 \%$ (UVC dose of $4.8 \mathrm{~kJ} / \mathrm{m}^{2}$ or $0.11 \mathrm{~kJ} / \mathrm{L}$ for $80 \%$ IMD removal) and $97 \%$ (UVC dose of $3.0 \mathrm{~kJ} / \mathrm{m}^{2}$ or $0.07 \mathrm{~kJ} / \mathrm{L}$ for $80 \%$ IMD removal), respectively. As for $\mathrm{S}_{2} \mathrm{O}_{8}{ }^{2-}$ consumption, after $60 \mathrm{~min}$ of the reaction the values were $0.05 \mathrm{mM}, 0.58 \mathrm{mM}$, and $1.5 \mathrm{mM}$ for initial concentrations of $0.147 \mathrm{mM}, 1.47 \mathrm{mM}$, and $2.94 \mathrm{mM}$, respectively. These results show that the generation of sulfate radicals by $\mathrm{S}_{2} \mathrm{O}_{8}{ }^{2-}$ photodecomposition (Reactions (R6-R8)) under 278-nm UVC-LED radiation has a significant effect on microcontaminant removal. In this regard, several authors have pointed out that these radicals react selectively via electron transfer with organic compounds against other radicals with a higher oxidative potential (such as hydroxyl radicals), which are non-selective [29]. This is an advantage of applying the UVD-LED $/ \mathrm{S}_{2} \mathrm{O}_{8}{ }^{2-}$ process to real municipal WWTP secondary effluent, where the scavenger effect of water matrices can significantly affect the efficiency of AOPs. 

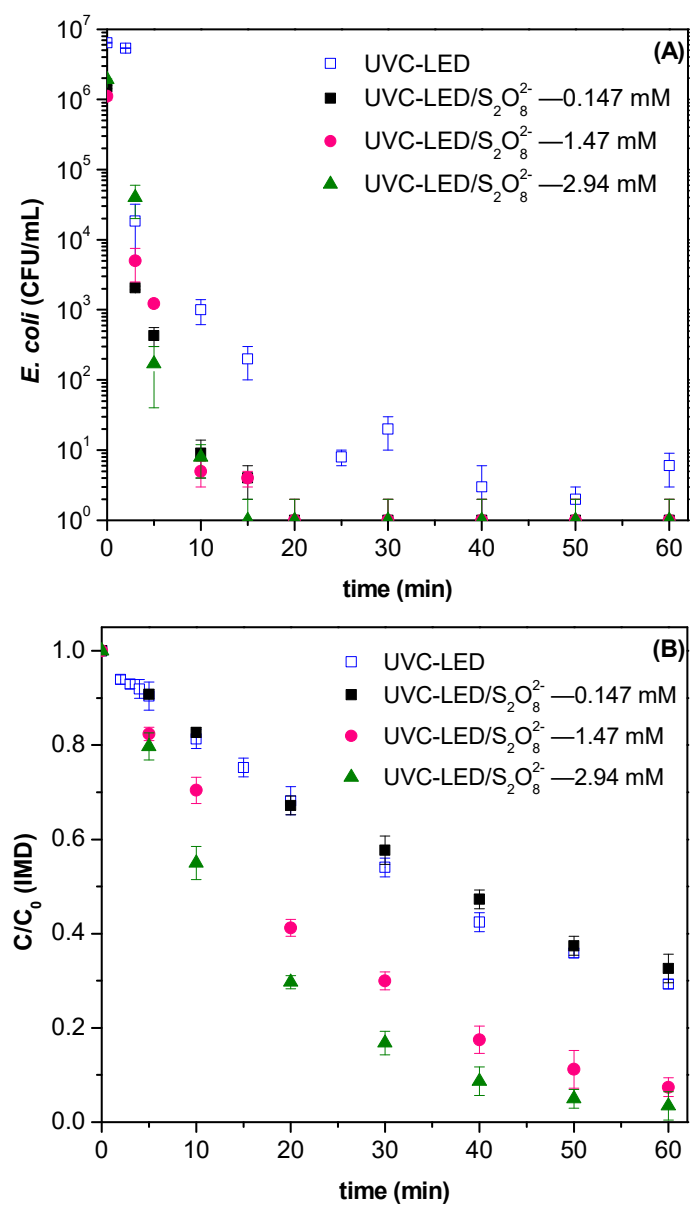

Figure 4. Effect of initial concentrations of $\mathrm{S}_{2} \mathrm{O}_{8}{ }^{2-}(0.147,1.47$, and $2.94 \mathrm{mM})$ on simultaneous E. coli inactivation (A) and IMD removal (B) by the UVC-LED $/ \mathrm{S}_{2} \mathrm{O}_{8}{ }^{2-}$ process.

Considering these results, using an initial $\mathrm{S}_{2} \mathrm{O}_{8}{ }^{2-}$ concentration of $1.47 \mathrm{mM}$ is recommended, thus preventing bacterial regrowth, and achieving more than $90 \%$ microcontaminant removal. In addition, it is important to note that working with high concentrations of this oxidant is not recommended, as it increases the salinity of the effluent. Comparing the results obtained with $\mathrm{H}_{2} \mathrm{O}_{2}$ and $\mathrm{S}_{2} \mathrm{O}_{8}{ }^{2-}$, it can be concluded that similar inactivation rates are achieved with both oxidants, whereas UVC-LED $/ \mathrm{S}_{2} \mathrm{O}_{8}{ }^{2-}$ is more efficient in terms of IMD removal. Nevertheless, the effect of both processes on the removal of other target microcontaminants, as well as treatment costs, should be considered before scaling up the process.

\subsection{Simultaneous E. coli Inactivation and IMD Removal by UVC-LED Mediated by the} $\mathrm{Fe}^{3+}-\mathrm{NTA}$ Complex with $\mathrm{H}_{2} \mathrm{O}_{2}$ and $\mathrm{S}_{2} \mathrm{O}_{8}{ }^{2-}$

It is commonly known that organic $\mathrm{Fe}^{3+}$ polycarboxylate complexes, compared to $\mathrm{Fe}^{3+}$ aqua complexes, have a higher molar absorption in the UV-Vis region and an extended working $\mathrm{pH}$ range, allowing them to work at $\mathrm{pH}$ values near to neutrality [30]. Mejri et al. [19] reported in 2020 that the decadic molar absorptivity of the $\mathrm{Fe}^{3+}-\mathrm{NTA}$ complex at 327-384 $\mathrm{nm}$ was $19.95 \mathrm{mM}^{-1} \cdot \mathrm{m}^{-1}$. The $\mathrm{Fe}^{3+}-\mathrm{NTA}$ has a maximum absorption between 258 and $273 \mathrm{~nm}$ (data not shown); hence, before starting this experimental work plan, the decadic molar absorptivity of the $\mathrm{Fe}^{3+}$-NTA complex was measured in the range 260-300 nm, since this is the wavelength range emitted by the UVC-LED device used in this work, which presents its maximum at $278 \mathrm{~nm}$. The decadic molar absorptivity was $493.05 \mathrm{mM}^{-1} \cdot \mathrm{m}^{-1}$, indicating high absorptivity at low wavelengths. The complex absorbs $96 \%$ more radiation at UVC than at the solar UV range; thus, a positive response can be expected when using the $\mathrm{Fe}^{3+}-\mathrm{NTA}$ complex under UVC-LED radiation. 
To test the treatment efficiency under UVC-LED radiation using iron complexes, the initial operating conditions were based on previous work conducted under solar natural radiation [19], as well as previous results shown in the sections above. These operating conditions were: $0.10 \mathrm{mM}$ of $\mathrm{Fe}^{3+}-\mathrm{NTA}$ complex at 1:1 molar ratio, and $1.47 \mathrm{mM}$ of each of the oxidants under study $\left(\mathrm{H}_{2} \mathrm{O}_{2}\right.$ and $\left.\mathrm{S}_{2} \mathrm{O}_{8}{ }^{2-}\right)$.

Figure 5 shows the normalized concentration of total dissolved iron $\left(\mathrm{Fe}_{\text {total }}\right)$ and $\mathrm{Fe}^{3+}-\mathrm{NTA}$ for each treatment. Note that a similar trend was observed for the decrease in the pseudo-first-order kinetics of $\mathrm{Fe}_{\text {total }}$ due to iron precipitation, and for $\mathrm{Fe}^{3+}-\mathrm{NTA}$ photodecomposition within the first $20 \mathrm{~min}$ of reaction, $0.015 \pm 0.001 \mathrm{~min}^{-1}\left(\mathrm{R}^{2}=0.972\right)$ and $0.016 \pm 0.001 \mathrm{~min}^{-1}\left(\mathrm{R}^{2}=0.988\right)$, respectively, for UVC-LED/Fe ${ }^{3+}-\mathrm{NTA} / \mathrm{H}_{2} \mathrm{O}_{2}$, whilst for UVC-LED $/ \mathrm{Fe}^{3+}-\mathrm{NTA} / \mathrm{S}_{2} \mathrm{O}_{8}{ }^{2-}$ the kinetic constants were $0.009 \pm 0.001 \mathrm{~min}^{-1}\left(\mathrm{R}^{2}=0.971\right)$ and $0.011 \pm 0.001 \mathrm{~min}^{-1}\left(\mathrm{R}^{2}=0.989\right)$, for $\mathrm{Fe}_{\text {total }}$ and $\mathrm{Fe}^{3+}-\mathrm{NTA}$, respectively. Comparing these treatments, the $\mathrm{Fe}_{\text {total }}$ precipitation and $\mathrm{Fe}^{3+}-\mathrm{NTA}$ photodecomposition were more pronounced when using $\mathrm{H}_{2} \mathrm{O}_{2}$ instead of $\mathrm{S}_{2} \mathrm{O}_{8}{ }^{2-}$, due to the higher oxidative potential of hydroxyl radicals than sulfate radicals against the complex, contributing to its decomposition in addition to the action of radiation. Then, a difference between $\mathrm{Fe}_{\text {total }}$ and the $\mathrm{Fe}^{3+}-\mathrm{NTA}$ concentration was observed for experiments conducted with $\mathrm{S}_{2} \mathrm{O}_{8}{ }^{2-}$, showing slightly more $\mathrm{Fe}_{\text {total }}$ than $\mathrm{Fe}^{3+}-\mathrm{NTA}$ complex in solution. This fact may be due to the high sulfate concentration generated by $\mathrm{S}_{2} \mathrm{O}_{8}{ }^{2-}$ decomposition (Reactions (R5) and (R6)), which can affect the iron measured in complex matrices, since no improvement is observed in terms of IMD removal after $20 \mathrm{~min}$.

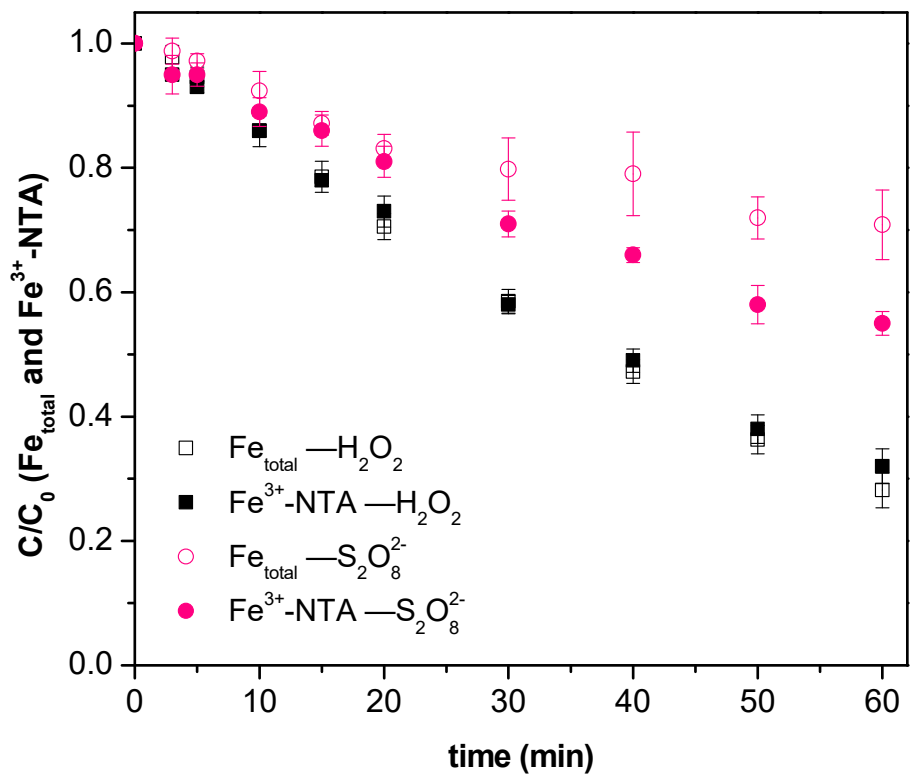

Figure 5. Normalized concentration of $\mathrm{Fe}_{\text {total }}$ precipitation and $\mathrm{Fe}^{3+}-\mathrm{NTA}$ photodecomposition by UVC-LEDs. Operating conditions: $0.10 \mathrm{mM}$ of $\mathrm{Fe}^{3+}-\mathrm{NTA}$ at a 1:1 molar ratio, and $1.47 \mathrm{mM}$ of each of the oxidants $\left(\mathrm{H}_{2} \mathrm{O}_{2}\right.$ and $\left.\mathrm{S}_{2} \mathrm{O}_{8}{ }^{2-}\right)$.

On the other hand, De Luca et al. [31] found in 2015 that the $\mathrm{Fe}^{3+}-\mathrm{NTA}$ photodecomposition under UVC ( $254 \mathrm{~nm})$ was higher than that obtained with other UV sources, such as UVA (365 nm) and simulated solar radiation. More than $90 \%$ of $\mathrm{Fe}^{3+}-\mathrm{NTA}$ was lost within the first $30 \mathrm{~min}$ under UVC (254 nm). In this study, more than $70 \%$ of $\mathrm{Fe}^{3+}-\mathrm{NTA}$ was lost within $60 \mathrm{~min}$ for the UVC-LED/Fe ${ }^{3+}-\mathrm{NTA} / \mathrm{H}_{2} \mathrm{O}_{2}$ system, while this value decreased to $40 \%$ for the UVC-LED $/ \mathrm{Fe}^{3+}-\mathrm{NTA} / \mathrm{S}_{2} \mathrm{O}_{8}{ }^{2-}$ system. In this way, $\mathrm{Fe}^{3+}-\mathrm{NTA}$ was more stable in comparison with the data reported by De Luca et al. in 2015 [31], probably because the UVC-LEDs used in this work had lower power.

Figure $6 \mathrm{~A}, \mathrm{~B}$ show the simultaneous $E$. coli inactivation and IMD removal by $\mathrm{Fe}^{3+}-\mathrm{NTA}$ with $\mathrm{H}_{2} \mathrm{O}_{2}$ and $\mathrm{S}_{2} \mathrm{O}_{8}{ }^{2-}$ under UVC-LED radiation (UVC-LED/Fe ${ }^{3+}-\mathrm{NTA} / \mathrm{H}_{2} \mathrm{O}_{2}$ and UVC$\mathrm{LED} / \mathrm{Fe}^{3+}-\mathrm{NTA} / \mathrm{S}_{2} \mathrm{O}_{8}{ }^{2-}$, respectively). As already shown in previous sections, the UVC- 
LED radiation was not able to achieve complete $E$. coli inactivation without regrowth at $24 \mathrm{~h}$, nor was it able to remove more than $70 \%$ of IMD after 60 min of treatment. Regarding E. coli K-12 inactivation, in both cases a reduction of 6 logs was achieved in $30 \mathrm{~min}$, requiring a $3.6 \mathrm{~kJ} / \mathrm{m}^{2}(0.08 \mathrm{~kJ} / \mathrm{L}) \mathrm{UVC}$ dose. Similar pseudo-first-order kinetic constants were obtained-0.43 $\pm 0.007 \mathrm{~min}^{-1}$ and $0.45 \pm 0.006 \mathrm{~min}^{-1}$ for UVC-LED/Fe ${ }^{3+}-\mathrm{NTA} / \mathrm{H}_{2} \mathrm{O}_{2}$ and UVC-LED $/ \mathrm{Fe}^{3+}-\mathrm{NTA} / \mathrm{S}_{2} \mathrm{O}_{8}{ }^{2-}$, respectively. The kinetic constants decreased compared with the assays in the absence of $\mathrm{Fe}^{3+}-\mathrm{NTA}$ (Section 3.1). This decrease was possibly due to the additional organic matter in solution provided by the complexing agent, and by iron complex loss as a result of photochemical and oxidation reactions. In addition, iron released by complex decomposition generated iron clusters in the reaction bulk, increasing the turbidity in the aqueous media. Fiorentino et al. [32] evaluated a new photo-Fenton process at neutral $\mathrm{pH}$ under $\mathrm{UVC}$ radiation $\left(\mathrm{UVC} / \mathrm{H}_{2} \mathrm{O}_{2} / \mathrm{IDS} \mathrm{Cu}\right.$ ) using an iminodisuccinic acid (IDS)-Cu complex, comparing with UVC $/ \mathrm{H}_{2} \mathrm{O}_{2} / \mathrm{Cu}, \mathrm{UVC} / \mathrm{H}_{2} \mathrm{O}_{2} / \mathrm{Fe}, \mathrm{H}_{2} \mathrm{O}_{2}$, and UVC when applied to urban wastewater disinfection. In this study, the formation of clusters (precipitates) was observed when an iron complex was used instead of a copper complex, these precipitates being the cause of a decrease in the inactivation efficiency.
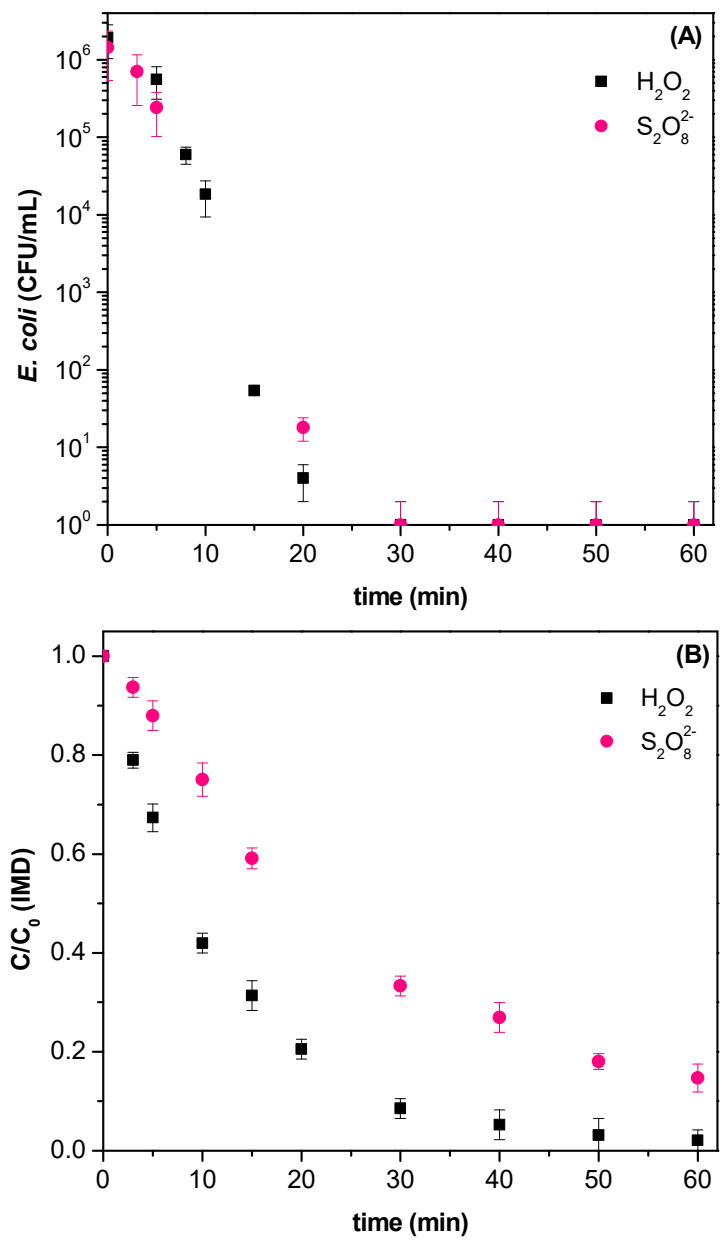

Figure 6. Simultaneous E. coli inactivation (A) and IMD removal (B) by UVC-LED/Fe ${ }^{3+}-\mathrm{NTA} / \mathrm{H}_{2} \mathrm{O}_{2}$ and UVC-LED $/ \mathrm{Fe}^{3+}-\mathrm{NTA} / \mathrm{S}_{2} \mathrm{O}_{8}{ }^{2-}$ systems. Operating conditions were: $0.10 \mathrm{mM}$ of $\mathrm{Fe}^{3+}-\mathrm{NTA}$ complex at a 1:1 molar ratio, and $1.47 \mathrm{mM}$ of each of the oxidants under study $\left(\mathrm{H}_{2} \mathrm{O}_{2}\right.$ and $\left.\mathrm{S}_{2} \mathrm{O}_{8}{ }^{2-}\right)$.

Concerning IMD removal, as shown in Figure 6B, more than $80 \%$ degradation was achieved with both treatments. The UVC-LED/Fe ${ }^{3+}-\mathrm{NTA} / \mathrm{H}_{2} \mathrm{O}_{2}$ system needed 20 min with a kinetic constant of $0.081 \pm 0.001 \mathrm{~min}^{-1}$ (UVC-LED dose of $2.4 \mathrm{~kJ} / \mathrm{m}^{2}$ or $0.05 \mathrm{~kJ} / \mathrm{L}$, Table 1), while for the UVC-LED $/ \mathrm{Fe}^{3+}-\mathrm{NTA} / \mathrm{S}_{2} \mathrm{O}_{8}{ }^{2-}$ system $55 \mathrm{~min}$ were required, presenting a lower kinetic constant equivalent to $0.033 \pm 0.001 \mathrm{~min}^{-1}$ (UVC-LED dose of 
$6.6 \mathrm{~kJ} / \mathrm{m}^{2}$ or $0.14 \mathrm{~kJ} / \mathrm{L}$, Table 1 ), to achieve the same IMD degradation percentage. The IMD degradation was strongly improved in the UVC-LED/ $/ \mathrm{Fe}^{3+}-\mathrm{NTA} / \mathrm{H}_{2} \mathrm{O}_{2}$ system compared to the UVC-LED $/ \mathrm{H}_{2} \mathrm{O}_{2}$ system, indicating that the $\mathrm{Fe}^{3+}-\mathrm{NTA}$ photodegradation (Reaction (R9)) involved extra $\mathrm{HO}^{\bullet}$ generation by Reactions (R12) and (R13), and possibly the participation of other less reactive radicals (Reactions (R9-R11)). The general mechanism of the ferric complex formed with nitrilotriacetic acid (NTA) exposed to UV radiation can be summarized as follows: $\mathrm{Fe}^{3+}-\mathrm{NTA}$ can generate $\mathrm{Fe}^{2+}$ ions and NTA free radicals by photoreduction through a ligand-to-metal charge transfer reaction (Reaction (R9)). The NTA radicals can react with $\mathrm{O}_{2}$ and $\mathrm{HO}^{-}$to form superoxide radical anions $\left(\mathrm{O}_{2}{ }^{\bullet-}\right)$ and $\mathrm{HO}^{\bullet}$ (Reactions (R11) and (R12)). In addition, when $\mathrm{H}_{2} \mathrm{O}_{2}$ is added, the $\mathrm{Fe}^{3+}-\mathrm{NTA}$ complex can react to generate $\mathrm{Fe}^{2+}$ and more NTA free radicals, as illustrated by Reaction (R10). However, the addition of organic matter by the complex, when $\mathrm{S}_{2} \mathrm{O}_{8}{ }^{2-}$ was used, slowed down the E. coli inactivation and IMD removal for the same molar concentration of oxidant. Interestingly, using $\mathrm{S}_{2} \mathrm{O}_{8}{ }^{2-}$ instead of $\mathrm{H}_{2} \mathrm{O}_{2}$ with the UVC-LED/ $\mathrm{Fe}^{3+}-\mathrm{NTA}$ system did not improve the process' efficiency. Theoretically, the $\mathrm{SO}_{4}{ }^{\bullet-}$ radical should be more efficient than $\mathrm{HO}^{\bullet}$ when working with complex matrices (simulated WWTP effluent) due to its selectivity, i.e., the use of selective oxidants such as $\mathrm{S}_{2} \mathrm{O}_{8}{ }^{2-}, \mathrm{SO}_{4}{ }^{\bullet-}$, or $\mathrm{S}_{2} \mathrm{O}_{8}{ }^{-}{ }^{-}$minimizes the parallel reactions with radical scavengers [33]. Even so, in the $\mathrm{UVC}-\mathrm{LED} / \mathrm{Fe}^{3+}-\mathrm{NTA} / \mathrm{S}_{2} \mathrm{O}_{8}{ }^{2-}$ system, complete inactivation of $E$. coli and more than $80 \%$ IMD removal was achieved, requiring slightly more time and a higher UVC dose for IMD removal (Table 1).

$$
\begin{gathered}
\mathrm{Fe}^{3+}-\mathrm{NTA}+\mathrm{hv} \rightarrow\left[\mathrm{Fe}^{3+}-\mathrm{NTA}\right]^{*} \rightarrow\left[\mathrm{Fe}^{3+}-\mathrm{NTA}^{*} \rightarrow \mathrm{Fe}^{2+}+\mathrm{NTA}^{\bullet}\right. \\
\mathrm{Fe}^{3+}-\mathrm{NTA}+2 \mathrm{H}_{2} \mathrm{O}_{2} \rightarrow \mathrm{Fe}^{2+}+\mathrm{NTA}^{\bullet}+2 \mathrm{HO}^{-}+\mathrm{O}_{2}^{\bullet-} \\
\mathrm{NTA}^{\bullet}+\mathrm{O}_{2} \rightarrow \mathrm{O}_{2}^{\bullet-}+\mathrm{NTA}_{\mathrm{ox}} \\
\mathrm{NTA}^{\bullet}+\mathrm{HO}^{-} \rightarrow \mathrm{HO}^{\bullet}+\mathrm{NTA}_{\mathrm{ox}} \\
\mathrm{Fe}^{2+}+\mathrm{H}_{2} \mathrm{O}_{2} \rightarrow \mathrm{Fe}^{3+}+\mathrm{HO}^{\bullet}+\mathrm{HO}^{-}
\end{gathered}
$$

The consumptions of both oxidants, considering simultaneous $E$. coli inactivation and IMD removal, were $1.20 \mathrm{mM}$ of $\mathrm{H}_{2} \mathrm{O}_{2}$ after 20 min of treatment and $0.30 \mathrm{mM}$ of $\mathrm{S}_{2} \mathrm{O}_{8}{ }^{2-}$ after $55 \mathrm{~min}$ of treatment, leading to a residual concentration of $0.29 \mathrm{mM}$ of $\mathrm{H}_{2} \mathrm{O}_{2}$ and $1.13 \mathrm{mM}$ of $\mathrm{S}_{2} \mathrm{O}_{8}{ }^{2-}$, which could maintain the inactivation of $E$. coli for $24 \mathrm{~h}$.

Overall, if the treatment goal is simultaneous disinfection and microcontaminant removal, although adding $\mathrm{Fe}^{3+}-\mathrm{NTA}$ slows down the bacteria inactivation with regard to UVC radiation only, the shorter treatment time to reach this objective at medium oxidant concentration is attained with UVC-LED/ $/ \mathrm{Fe}^{3+}-\mathrm{NTA} / \mathrm{H}_{2} \mathrm{O}_{2}-0.1 \mathrm{mM} / 1.47 \mathrm{mM}$, in $30 \mathrm{~min}$ (Table 1), close to the results of the UVC-LED $/ \mathrm{S}_{2} \mathrm{O}_{8}{ }^{2-}$ system-2.94 $\mathrm{mM}$ with $25 \mathrm{~min}$, but using a high $\mathrm{S}_{2} \mathrm{O}_{8}{ }^{2-}$ concentration. The final decision should be based on the specific characteristics of the wastewater and the treatment cost.

\subsection{Comparison of the UVC-LED Treatment with Conventional Chlorination}

Currently, chlorination is the most widely used disinfection treatment applied as a tertiary treatment either for drinking water or wastewater reuse in agriculture. For this reason, chlorination was also addressed evaluating simultaneous $E$. coli inactivation and IMD removal, in order to compare it to the UVC-LED process.

Chlorination was evaluated for up to $30 \mathrm{~min}$ of the reaction, as the time set to carry out the conventional treatment is in the range from 20 to $30 \mathrm{~min}$. Figure 7 shows the inactivation of $E$. coli for three initial concentrations $(0.028,0.14$, and $0.28 \mathrm{mM}$ of chlorine). For the two higher concentrations, complete $E$. coli inactivation was achieved, requiring $5 \mathrm{~min}$ for $0.28 \mathrm{mM}$ of chlorine and $10 \mathrm{~min}$ for $0.14 \mathrm{mM}$. For the lowest concentration of chlorine $(0.028 \mathrm{Mm}-1 \mathrm{mg} / \mathrm{L})$, it was only possible to reduce 3 logs after $30 \mathrm{~min}$. Based on free chlorine detected after $24 \mathrm{~h}$ of the reaction, the best chlorine concentration was 
$0.14 \mathrm{mM}(5 \mathrm{mg} / \mathrm{L})$, for which the residual free chloride concentration at $24 \mathrm{~h}$ was $0.43 \mathrm{mg} / \mathrm{L}$, whereas a residual free chloride concentration of $2.07 \mathrm{mg} / \mathrm{L}$ was detected for $0.28 \mathrm{mM}$ (10 mg/L).

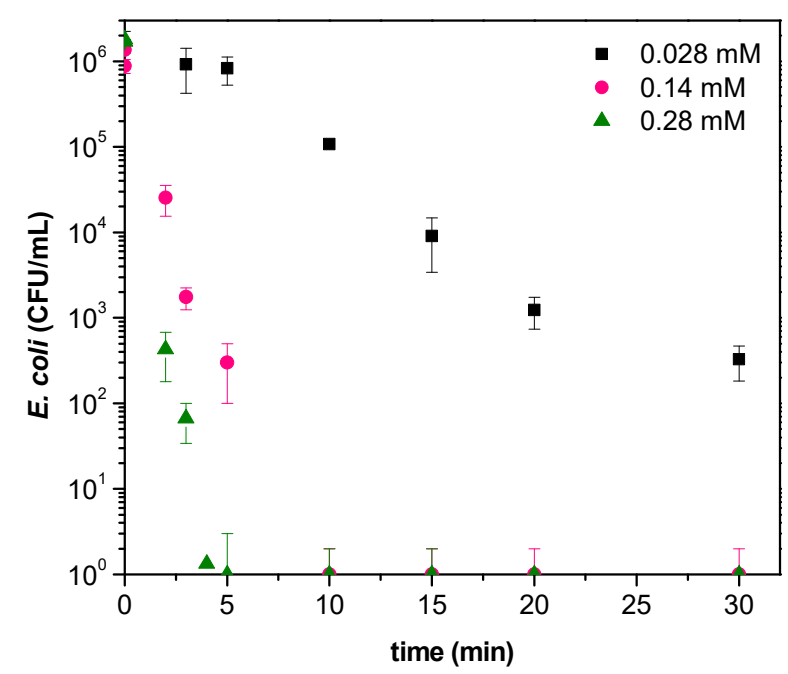

Figure 7. E. coli inactivation by chlorination with different initial concentrations of chlorine $(0.028$, 0.14 , and $0.28 \mathrm{mM})$.

On the other hand, IMD concentration remained at its initial value for all chlorine concentrations, indicating that the chlorination was not able to degrade the organic contaminant. Hence, in terms of E. coli inactivation, chlorination was the most effective treatment (Table 1) compared to the UVC-LED treatments addressed in this work. However, it is important to note that no more than $30 \mathrm{~min}$ were required by the UVC-LED processes to achieve complete disinfection. In addition, these processes present important advantages, since they are harmless, i.e., they cause no secondary reactions with natural organic or inorganic matter (NOM or NIM), avoiding disinfection byproduct (DBP) formation, which is the main disadvantage of chlorination.

\section{Conclusions}

Four AOPs based on UVC-LED radiation with different oxidants have been evaluated for simultaneous disinfection and decontamination, and compared with chlorination. A UVC-LED system alone was not efficient for either E. coli inactivation or IMD removal, requiring the addition of an oxidant. Different initial concentrations were tested for the UVC-LED $/ \mathrm{H}_{2} \mathrm{O}_{2}$ and UVC-LED $/ \mathrm{S}_{2} \mathrm{O}_{8}{ }^{2-}$ systems, with $1.47 \mathrm{mM}$ being the most efficient concentration for both oxidants. Under these conditions, E. coli inactivation below the DL was achieved without regrowth at $24 \mathrm{~h}$, while $73 \%$ and more than $90 \%$ IMD removal were achieved with $\mathrm{H}_{2} \mathrm{O}_{2}$ and $\mathrm{S}_{2} \mathrm{O}_{8}{ }^{2-}$, respectively. It is important to note that the contribution of $\mathrm{H}_{2} \mathrm{O}_{2}$ photoactivation was very low for UVC-LED at $278 \mathrm{~nm}$.

On the other hand, the addition of $\mathrm{Fe}^{3+}-\mathrm{NTA}$ improved the efficiency of the process in terms of IMD degradation in comparison with UVC-LED $/ \mathrm{H}_{2} \mathrm{O}_{2}$ and UVC-LED $/ \mathrm{S}_{2} \mathrm{O}_{8}{ }^{2-}$. E. coli inactivation was affected by the increase in organic matter related to the addition of NTA, and possibly by the iron precipitation, which slowed down the kinetics regarding the UVC-LED $/ \mathrm{H}_{2} \mathrm{O}_{2}$ and UVC-LED $/ \mathrm{S}_{2} \mathrm{O}_{8}{ }^{2-}$ processes. Even so, complete inactivation in less than $30 \mathrm{~min}$ without regrowth at $24 \mathrm{~h}$ was achieved due to the high contribution of UVC irradiance. More studies should be carried out in order to explore the direct benefits of using of UVC-LED devices with iron complexes, since a high reduction of IMD treatment times was observed. Furthermore, the short reaction times for simultaneous bacteria inactivation and organic contaminant removal encourage the study of the process in continuous flow. 
Author Contributions: Conceptualization, S.M.-C. and J.A.S.P.; methodology, S.M.-C., P.S.-M. and I.D.1.O.; formal analysis, S.M.-C., P.S.-M. and I.D.1.O.; investigation, S.M.-C. and E.G.-A.; resources, J.A.S.P.; writing —original draft preparation, S.M.-C. and I.D.1.O.; writing—review and editing, J.A.S.P. and J.L.C.L.; supervision, J.A.S.P.; project administration, J.A.S.P. and J.L.C.L.; funding acquisition, J.L.C.L. All authors have read and agreed to the published version of the manuscript.

Funding: This research was funded by Life Phoenix project, grant number LIFE19 ENV/ES/000278. Institutional Review Board Statement: Not applicable.

Informed Consent Statement: Not applicable.

Acknowledgments: P. Soriano-Molina is grateful to the Andalusian Regional Government for her research contract (DOC_00544). I. De la Obra wishes to thank the Andalusian Regional Government (P12RNM-1437). S. Miralles wishes to thank ANID through the SERC-Chile (ANID/FONDAP/15110019) and the project ANID/FONDECYT Regular/1210358. The authors would like to acknowledge the contribution of the LIFE PHOENIX project, financed by the European Union under Grant Agreement No. LIFE19 ENV/ES/000278.

Conflicts of Interest: The authors declare no conflict of interest.

\section{References}

1. Pichel, N.; Vivar, M.; Fuentes, M. The problem of drinking water access: A review of disinfection technologies with an emphasis on solar treatment methods. Chemosphere 2019, 218, 1014-1030. [CrossRef]

2. Compagni, R.D.; Gabrielli, M.; Polesel, F.; Turolla, A.; Trapp, S.; Vezzaro, L.; Antonelli, M. Risk assessment of contaminants of emerging concern in the context of wastewater reuse for irrigation: An integrated modelling approach. Chemosphere 2020, 242, 125185. [CrossRef]

3. European Union. Commission Implementing Decision 2020/1161/EU of 4 August 2020 establishing a watch list of substances for Union-wide monitoring in the field of water policy pursuant to Directive 2008/105/EC of the European Parliament and of the Council. Off. J. Eur. Union 2020, L257, 32-35.

4. Brillas, E.; Garcia-Segura, S. Benchmarking recent advances and innovative technology approaches of Fenton, photo-Fenton, electro-Fenton, and related processes: A review on the relevance of phenol as model molecule. Sep. Purif. Technol. 2020, 237, 116337. [CrossRef]

5. Rizzo, L.; Malato, S.; Antakyali, D.; Beretsou, V.G.; Đolić, M.B.; Gernjak, W.; Heath, E.; Ivancev-Tumbas, I.; Karaolia, P.; Ribeiro, A.R.L.; et al. Consolidated vs new advanced treatment methods for the removal of contaminants of emerging concern from urban wastewater. Sci. Total Environ. 2019, 655, 986-1008. [CrossRef]

6. Guzman, P.V.-; Giannakis, S.; Rtimi, S.; Grandjean, D.; Bensimon, M.; de Alencastro, L.F.; Torres-Palma, R.; Pulgarin, C. A green solar photo-Fenton process for the elimination of bacteria and micropollutants in municipal wastewater treatment using mineral iron and natural organic acids. Appl. Catal. B Environ. 2017, 219, 538-549. [CrossRef]

7. Jain, B.; Singh, A.K.; Kim, H.; Lichtfouse, E.; Sharma, V.K. Treatment of organic pollutants by homogeneous and heterogeneous Fenton reaction processes. Environ. Chem. Lett. 2018, 16, 947-967. [CrossRef]

8. Deng, J.; Feng, S.; Zhang, K.; Li, J.; Wang, H.; Zhang, T.; Ma, X. Heterogeneous activation of peroxymonosulfate using ordered mesoporous $\mathrm{Co}_{3} \mathrm{O}_{4}$ for the degradation of chloramphenicol at neutral pH. Chem. Eng. J. 2017, 308, 505-515. [CrossRef]

9. Rodríguez-Chueca, J.; Guerra-Rodríguez, S.; Raez, J.M.; López-Muñoz, M.-J.; Rodríguez, E. Assessment of different iron species as activators of $\mathrm{S}_{2} \mathrm{O}_{8}{ }^{2-}$ and $\mathrm{HSO}_{5}{ }^{-}$for inactivation of wild bacteria strains. Appl. Catal. B Environ. 2019, 248, 54-61. [CrossRef]

10. Ahile, U.J.; Wuana, R.; Itodo, A.U.; Sha'Ato, R.; Dantas, R.F. A review on the use of chelating agents as an alternative to promote photo-Fenton at neutral pH: Current trends, knowledge gap and future studies. Sci. Total Environ. 2020, 710, 134872. [CrossRef] [PubMed]

11. Fiorentino, A.; Esteban, B.; Garrido-Cardenas, J.A.; Kowalska, K.; Rizzo, L.; Aguera, A.; Pérez, J.A.S. Effect of solar photo-Fenton process in raceway pond reactors at neutral $\mathrm{pH}$ on antibiotic resistance determinants in secondary treated urban wastewater. J. Hazard. Mater. 2019, 378, 120737. [CrossRef]

12. López-Vinent, N.; Cruz-Alcalde, A.; Romero, L.; Chávez, M.; Marco, P.; Giménez, J.; Esplugas, S. Synergies, radiation and kinetics in photo-Fenton process with UVA-LEDs. J. Hazard. Mater. 2019, 380, 120882. [CrossRef]

13. Collivignarelli, M.C.; Abbà, A.; Miino, M.C.; Caccamo, F.M.; Torretta, V.; Rada, E.C.; Sorlini, S. Disinfection of Wastewater by UV-Based Treatment for Reuse in a Circular Economy Perspective. Where Are We at? Int. J. Environ. Res. Public Health 2020, 18, 77. [CrossRef] [PubMed]

14. Guerra-Rodríguez, S.; Ribeiro, A.R.L.; Ribeiro, R.S.; Rodríguez, E.; Silva, A.M.; Rodríguez-Chueca, J. UV-A activation of peroxymonosulfate for the removal of micropollutants from secondary treated wastewater. Sci. Total Environ. 2021, 770, 145299. [CrossRef] 
15. Giannakis, S.; Androulaki, B.; Comninellis, C.; Pulgarin, C. Wastewater and urine treatment by UVC-based advanced oxidation processes: Implications from the interactions of bacteria, viruses, and chemical contaminants. Chem. Eng. J. 2018, 343, $270-282$. [CrossRef]

16. Rivas, G.; Carra, I.; Sánchez, J.G.; López, J.L.C.; Malato, S.; Pérez, J.S. Modelling of the operation of raceway pond reactors for micropollutant removal by solar photo-Fenton as a function of photon absorption. Appl. Catal. B Environ. 2015, 178, $210-217$. [CrossRef]

17. Aillet, T.; Loubiere, K.; Dechy-Cabaret, O.; Prat, L.E. Accurate Measurement of the Photon Flux Received Inside Two Continuous Flow Microphotoreactors by Actinometry. Int. J. Chem. React. Eng. 2014, 12, 257-269. [CrossRef]

18. European Union. Commission Implementing Decision 2018/840/EU of 5th June 2018 establishing a watch list of substances for Union-wide monitoring in the field of water policy pursuant to Directive 2008/105/EC of the European Parliament and of the Council and repealing Commission Implementing Decision (EU) 2015/495. Off. J. Eur. Union 2018, L141, 9-12.

19. Mejri, A.; Soriano-Molina, P.; Miralles-Cuevas, S.; Pérez, J.A.S. Fe ${ }^{3+}-\mathrm{NTA}$ as iron source for solar photo-Fenton at neutral pH in raceway pond reactors. Sci. Total Environ. 2020, 736, 139617. [CrossRef]

20. EPA. Guidelines for Water Reuse; EPA/600/R-12/618; Environmental Protection Agency: Wahington, DC, USA, 2012.

21. Liang, C.; Huang, C.-F.; Mohanty, N.; Kurakalva, R.M. A rapid spectrophotometric determination of persulfate anion in ISCO. Chemosphere 2008, 73, 1540-1543. [CrossRef]

22. Zhang, Y.; Chelme-Ayala, P.; Klamerth, N.; El-Din, M.G. Application of UV-irradiated Fe(III)-nitrilotriacetic acid (UV-Fe(III)NTA) and UV-NTA-Fenton systems to degrade model and natural occurring naphthenic acids. Chemosphere 2017, 179, 359-366. [CrossRef]

23. García-Fernández, I.; López, M.I.P.; Oller, I.; Fernández-Ibáñez, P. Bacteria and fungi inactivation using $\mathrm{Fe}^{3+} / \mathrm{sunlight,}^{2}$ $\mathrm{H}_{2} \mathrm{O}_{2}$ /sunlight and near neutral photo-Fenton: A comparative study. Appl. Catal. B Environ. 2012, 121-122, 20-29. [CrossRef]

24. European Union. Regulation (EU) 2020/741 of the european parliament and of the council of 25 May 2020 on minimum requirements for water reuse. Off. J. Eur. Union 2020, L177, 32-55.

25. Acosta-Rangel, A.; Sánchez-Polo, M.; Polo, A.; Rivera-Utrilla, J.; Berber-Mendoza, M. Sulfonamides degradation assisted by UV, UV/H2O2 and UV/K2S2O8: Efficiency, mechanism and byproducts cytotoxicity. J. Environ. Manag. 2018, 225, 224-231. [CrossRef] [PubMed]

26. De la Obra, I.; Esteban, B.; Rivas, G.; Casas, J.L.; Pérez, J.L.S. Continuous flow disinfection of WWTP secondary effluents by solar photo Fenton at neutral pH in raceway pond reactors at pilot plant scale. Appl. Catal. B Environ. 2019, 247, 115-123. [CrossRef]

27. Sichel, C.; Fernández-Ibáñez, P.; De Cara, M.; Tello, J. Lethal synergy of solar UV-radiation and $\mathrm{H}_{2} \mathrm{O}_{2}$ on wild Fusarium solani spores in distilled and natural well water. Water Res. 2009, 43, 1841-1850. [CrossRef] [PubMed]

28. Sánchez-Montes, I.; García, I.S.; Ibañez, G.R.; Aquino, J.M.; Polo-López, M.I.; Malato, S.; Oller, I. UVC-based advanced oxidation processes for simultaneous removal of microcontaminants and pathogens from simulated municipal wastewater at pilot plant scale. Environ. Sci. Water Res. Technol. 2020, 6, 2553-2566. [CrossRef]

29. Zhou, K.; Wang, Z.; Wang, X.; Jiao, G.; Li, Y.; Sun, S.-P.; Chen, X.D. Degradation of emerging pharmaceutical micropollutants in municipal secondary effluents by low-pressure UVC-activated $\mathrm{HSO}_{5}{ }^{-}$and $\mathrm{S}_{2} \mathrm{O}_{8}{ }^{2-}$ AOPs. Chem. Eng. J. 2020, $393,124712$. [CrossRef]

30. Perini, J.A.L.; Tonetti, A.L.; Vidal, C.; Montagner, C.C.; Nogueira, R.F.P. Simultaneous degradation of ciprofloxacin, amoxicillin, sulfathiazole and sulfamethazine, and disinfection of hospital effluent after biological treatment via photo-Fenton process under ultraviolet germicidal irradiation. Appl. Catal. B Environ. 2018, 224, 761-771. [CrossRef]

31. De Luca, A.; Dantas, R.F.; Esplugas, S. Study of Fe(III)-NTA chelates stability for applicability in photo-Fenton at neutral pH. Appl. Catal. B Environ. 2015, 179, 372-379. [CrossRef]

32. Fiorentino, A.; Cucciniello, R.; Di Cesare, A.; Fontaneto, D.; Prete, P.; Rizzo, L.; Corno, G.; Proto, A. Disinfection of urban wastewater by a new photo-Fenton like process using $\mathrm{Cu}$-iminodisuccinic acid complex as catalyst at neutral $\mathrm{pH}$. Water Res. 2018, 146, 206-215. [CrossRef] [PubMed]

33. Silva, G.D.; Marson, E.O.; Batista, L.L.; Ueira-Vieira, C.; Starling, M.C.V.; Trovó, A.G. Contrasting the performance of photo-Fenton at neutral $\mathrm{pH}$ in the presence of different organic iron-complexes using hydrogen peroxide or persulfate as oxidants for naproxen degradation and removal of antimicrobial activity. Process. Saf. Environ. Prot. 2021, 147, 798-807. [CrossRef] 